\title{
Blok Aksilar dengan Panduan Ultrasonografi pada Operasi Debridement Lengan Bawah Pasien Systemic Lupus Erythematosus, Gagal Ginjal Kronik, Sirosis Hepatis, dan Gagal Jantung
}

\author{
Mohamad Andy Prihartono, Dedi Fitri Yadi, Erwin Pradian \\ Departemen Anestesi dan Terapi Intensif \\ Fakultas Kedokteran Universitas Padjadjaran Rumah Sakit Dr. Hasan Sadikin Bandung
}

\begin{abstract}
Abstrak
Blok aksilar sangat menguntungkan dilakukan pada operasi daerah lengan bawah. Pasien wanita berusia 28 tahun dengan diagnosis systemic lupus erithematosus (SLE), gagal ginjal kronik, sirosis hepatis dan gagal jantung, direncanakan operasi nekrotomi debridement di lengan bawah di Rumah Sakit Dr. Hasan Sadikin Bandung pada Maret 2012. Dilakukan anestesi blok aksilar dengan panduan ultrasound Sonosite M Turbo menggunakan high frequency probe linear, jarum stimulasi $50 \mathrm{~mm}$ dan nerve stimulator dengan obat anestesi lokal bupivakain 0,5\% dengan adjuvan epinefrin 1:200.000. Keberhasilan blok aksiler dikonfirmasi dengan menstimulasi sensoris dan nervus motorik yang telah diblok. Blok tercapai secara sempurna dalam waktu \pm 15 menit. Operasi dilakukan setelah blok tercapai dan operasi berlangsung selama 1 jam. Simpulan, blok aksilar dengan panduan ultrasound memberikan hasil yang memuaskan dengan angka keberhasilan yang tinggi. Pada pasien ini sangat menguntungkan dilakukan anestesi regional blok saraf perifer dibandingkan dengan anestesi umum karena komplikasi penyakit yang banyak.
\end{abstract}

Kata kunci: Blok aksilar, systemic lupus eritematosus, ultrasounografi

\section{Axillary Block with Ultrasound Guided for Debridement of the Forearm in Patient with Systemic Lupus Erythematous, Chronic Renal Failure, Hepatic Cirrhosis, and Congestive Heart Disease}

\begin{abstract}
Axillary block is beneficial when applied to a forearm operation. A 28-year-old female patient diagnosed with systemic lupus erythematosus, chronic renal failure, hepatic cirrhosis and heart failure, was planned for necrotomy debridement operation of the forearm in Dr. Hasan Sadikin Hospital-Bandung in March 2012. An axillary block anesthesia was done with Sonosite M Turbo ultrasound guidance that used high frequency linear probe, $50 \mathrm{~mm}$ stimulating needle, and nerve stimulator containing bupivacaine $0.5 \%$ and epinephrine adjuvant 1:200,000. The operation can be initiated after the block was achieved and the duration of operation was 1 hour. In conclusions, axillary block with ultrasound guidance gives satisfying result with higher success rate. Peripheral nerve block (regional anesthesia) is more beneficial to this patient than general anesthesia due to multiple complications.
\end{abstract}

Key words: Axillary block, systemic lupus erythematosus, ultrasound

Korespondensi: M. Andy Prihartono, dr., SpAn, M.Kes Departemen Anestesiologi dan Terapi Intensif, Fakultas Kedokteran Universitas Padjadjaran Jl. Pasteur No. 38, Bandung , mobile 081320008599, email andyprihartono@ gmail.com 


\section{Pendahuluan}

Teknik blokade aksiler adalah blokade pleksus brakialis yang sering dilakukan dan memiliki beberapa keuntungan. Teknik tersebut mudah dilakukan dengan efek samping lebih rendah bila dibandingkan dengan teknik blok pleksus brakialis yang lain. Blok aksiler akan menjadi lebih mudah lagi bila dilakukan menggunakan panduan ultrasonografi, karena lokasi nervus yang superfisial dengan keakuratan blok lebih tinggi karena visulisasi pada tiap nervus dapat terlihat dengan jelas. ${ }^{1,2}$

Blok aksiler dilakukan terhadap 4 nervus, yaitu nervus medialis, ulnaris, radialis, serta muskulokutaneus. Panduan alat ultrasonografi dapat memperlihatkan posisi nervus yang ada di sekitar arteri aksilaris menjadi lebih jelas. Keuntungan penggunaan alat ini adalah tingkat keberhasilan blok lebih tinggi dengan volume anestetik lokal lebih sedikit dan dapat melihat langsung penyebaran obat anestesi pada saat disuntikkan pada sekitar nervus yang dituju, sehingga meningkatkan keberhasilan blokade yang diinginkan ${ }^{1-3}$

Alat-alat lain yang digunakan adalah jarum stimulasi dan juga nerve stimulator. Kedua alat tersebut digunakan untuk melihat stimulasi pada setiap nervus, sehingga kita dapat melihat apakah nervus yang kita tuju dan terlihat pada ultrasonografi sesuai dengan stimulasinya.,4

\section{Laporan Kasus}

Seorang wanita usia 8 tahun dengan diagnosis sirosis hepatis e.c. hepatitis B dengan chronic kidney disease (CKD) stage 5 on hemodialisys e.c. lupus nefritis, systemic lupus erytematosus (SLE), dan gagal jantung klasifikasi fungsional kelas II. Pasien dikonsulkan dari sejawat bedah plastik dengan necrotic tissue pada antebrachii sinistra yang direncanakan operasi nekrotomi debridement.

Pemeriksaan fisis didapatkan hasil keadaan umum kompos mentis, tampak sakit sedang, tekanan darah 160/90 $\mathrm{mmHg}$, frekuensi nadi $100 \mathrm{x} /$ menit, frekuensi napas $24 \mathrm{x} /$ menit, suhu $37,2^{\circ} \mathrm{C}$, edema pitting pada kedua ekstremitas bawah, dan pemeriksaan fisis lain dalam batas normal.

Padapemeriksaan laboratorium didapatkan hasil hemoglobin $8,7 \mathrm{~g} / \mathrm{dL}$, hematokrit $27 \%$, leukosit $5.600 / \mathrm{mm}^{3}$, trombosit $89.000 / \mathrm{mm}^{3}$, albumin 2,9 g/dL, ureum $91 \mathrm{~g} / \mathrm{dL}$, kreatinin 4,72 g/dL, gula darah sewaktu $111 \mathrm{mg} / \mathrm{dL}$, natrium $138 \mathrm{meq} / \mathrm{L}$, kalium 4,3 meq/L, PT 13,8 detik, INR 1,19 detik, aPTT 35,5 detik. Pemeriksaan elektrokardiografi memberikan hasil gambaran sinus takikardia dengan denyut jantung $100 \mathrm{x} /$ menit.

Pasien status fisis ASA 3 dan direncanakan dilakukan anestesi regional blok saraf perifer menggunakan teknik blok saraf aksiler dengan panduan ultrasonografi dan nerve stimulator.

Pasien diposisikan tidur terlentang dengan posisi lengan kiri abduksi sejauh $90^{\circ}$. Resolusi ultrasonografi diatur dengan resolusi general memakai kedalaman $3 \mathrm{~cm}$. Setelah dilakukan aseptik dan antiseptik, probe linear diletakkan dengan posisi short axis untuk melihat arteri aksilaris, lalu diidentifikasi posisi nervus di sekitar arteri aksilaris yaitu medianus, ulnaris, radialis yang memberi gambaran hiperekoik, identifikasi juga nervus muskulokutaneus di lateral arteri aksilaris serta terletak antara otot bisep dan korakobrakialis. Sebaiknya semua gambaran tersebut berada di dalam satu layar untuk memudahkan operator melakukan blok pada semua nervus.

Jarum diinsersikan secara in plane untuk dapat melihat keseluruhan jarum pada layar ultrasonografi dengan jarum dari arah sefalad. Pertama kali dilakukan deposit obat anestesi lokal di daerah posterior arteri aksilaris, yaitu di nervus radialis dengan melihat rangsangan motorik pada daerah jari menggunakan nerve stimulator. Deposit obat berikutnya dilakukan di sebelah anterior lokasi arteri aksilaris, yaitu di sekitar nervus medialis dan nervus ulnaris sambil melihat efek stimulasi motorik, tampak anestetik lokal tersebut mengelilingi seluruh bagian arteri; lalu jarum diarahkan menuju lokasi nervus muskulokutaneus sambil melihat timbulnya stimulasi motorik dan deposit obat anestesi lokal sampai mengelilingi nervus.

Total obat anestesi lokal yang dimasukkan adalah $12 \mathrm{~mL}$ bupivakain $0,5 \%$ dengan adjuvan 


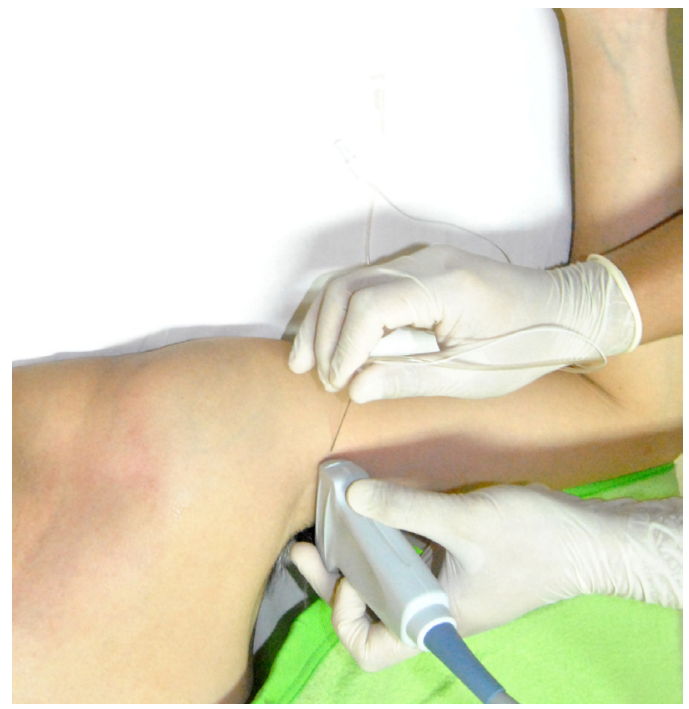

Gambar Posisi Saat Dilakukan Anestesia Blok Aksilar dengan Panduan Ultrasonografi

epinefrin 1:200.000. Penyebaran obat anestesi lokal di sekeliling arteri sangat menentukan keberhasilan blok ini, untuk menuju nervus yang akan diblok, arah jarum dapat berubah 2-3 kali. Konfirmasi keberhasilan blok yaitu dengan memeriksa sensoris dan motorik tiap nervus.

\section{Pembahasan}

Teknik blokade aksiler sering digunakan pada operasi lengan bawah dan merupakan teknik yang mudah untuk dilakukan. Teknik ini sering dilakukan dengan metode blind mengandalkan anatomi arteri aksilaris sebagai penanda. Obat anestesi lokal disuntikkan di sekitar arteri aksilaris dalam jumlah yang banyak sehingga deposit anestetik akan menggenangi seluruh daerah nervus., ${ }^{3,4}$ Angka tingkat keberhasilan teknik blok ini sangat rendah, terutama untuk blok nervus muskulokutaneus yang letaknya jauh dari arteri aksilaris, sehingga meskipun dengan penambahan volume anestetik lokal tetap saja sulit memblok nervus ini. ${ }^{1,2}$

Teknik blok aksiler dapat dilakukan dengan memakai panduan nerve stimulator. Dengan panduan alat ini blok yang dihasilkan menjadi lebih baik lagi dibandingkan dengan cara blind.

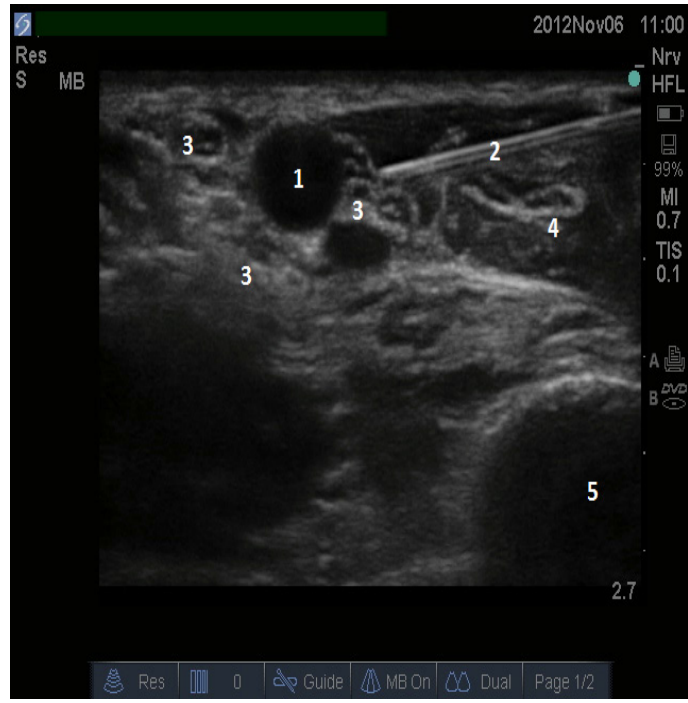

Keterangan:

1. Arteri aksilaris

2. Jarum

3. Saraf

4. Saraf musculokutaneus

5. Humerus

Jarum yang digunakan pada teknik blok ini merupakan jarum khusus untuk melakukan stimulasi saraf. Nervus yang menjadi tujuan akan diidentifikasi memakai bantuan jarum stimulasi dan nerve stimulator dengan melihat respons motorik pada tiap nervus yang dituju. Setelah mendapatkan gerakan motorik nervus yang dituju, lalu anestetik lokal dimasukkan di sekitar nervus tersebut. Meskipun dengan memakai bantuan kedua alat tersebut, blokade saraf ini masih sering mengalami kegagalan karena penyebaran anestetik lokal tidak dapat dilihat secara langsung. ${ }^{1}$

Denganmempergunakanalatultrasonografi sebagai panduan pada saat melakukan blokade saraf tepi, angka keberhasilan blokade menjadi lebih tinggi, hal ini karena kita dapat melihat secara langsung saraf yang dituju dan melihat penyebaran obat anestesi lokal. Ultrasonografi juga dapat diatur pada tingkat resolusi general dan menggunakan tipe high frequency linear probe dengan kedalaman $3 \mathrm{~cm}$. Semua nervus dapat dilihat dengan jelas apabila mengetahui letak anatomi dari tiap nervus tersebut. Jarum stimulasi disuntikkan dengan cara in plane 
sejajar probe sehingga seluruh bagian jarum akan terlihat. Dengan memakai cara in plane maka risiko komplikasi penyuntikan ke dalam arteri dapat dihindari. Setelah ujung jarum ini berada di dekat nervus yang dituju, konfirmasi dilakukan memakai nerve stimulator dengan melihat gerakan motorik akibat efek stimulasi nervus tersebut, lalu masukkan anestetik lokal dengan cara melihat langsung penyebarannya di layar ultrasonografi berupa gambaran hitam mengelilingi nervus yang berwarna putih atau biasa disebut "Doughnut sign", 1,2

Penggunaan bantuan alat nerve stimulator dan ultrasonografi akan lebih mempermudah saat melakukan blokade pada saraf tepi dengan tingkat keberhasilan yang lebih tinggi serta dapat terhindar dari komplikasi. Keuntungan lainnya adalah volume obat anestesi lokal yang digunakan menjadi lebih sedikit sehingga blok menjadi lebih efektif. ${ }^{2}$ Pada beberapa literatur digunakan volume obat anestesi lokal 20-25 $\mathrm{mL}$, sedangkan pada pasien ini volume obat anestesi total yang digunakan sebanyak $12 \mathrm{~mL}$ bupivakain 0,5\% ditambah adjuvan epinefrin 1:200.000 dan blok dapat tercapai sempurna dalam waktu 15 menit dengan durasi blokade selama 12 jam.

Penanganan anestesi pada pasien dengan SLE akan sangat bergantung pada beratnya disfungsi organ yang ada. Pada pasien seperti ini, pemilihan teknik anestesi regional blokade aksilar dapat dijadikan sebagai pilihan karena dapat meminimalkan respons stres terhadap tubuh yang diakibatkan karena efek obat-obat anestesi sehingga akan semakin memperberat disfungsi organ yang telah terjadi. Dengan terdapat disfungsi organ ini maka penggunaan obat anestesi harus diberikan dengan jumlah yang paling minimal. ${ }^{4-6}$ Pada pasien ini telah diberikan obat anestesi lokal bupivakain 0,5\% hanya sebanyak $12 \mathrm{~mL}$. Hemodinamik selama operasi tetap stabil, karena fungsi fisiologis pasien yang ada dapat tetap dipertahankan dan tidak terganggu oleh efek obat yang diberikan. Selain itu, efek analgetik pascaoperasi blokade yang dilakukan dapat bertahan sampai 12 jam pascaoperasi, sehingga pasien dapat terbebas dari nyeri yang dapat menimbulkan dampak lain yang dapat memperburuk kondisi pasien yang sudah ada.

\section{Simpulan}

Blok saraf aksiler merupakan teknik blokade saraf perifer pleksus brakialis yang mudah dilakukan dengan komplikasi minimal apabila dibandingkan dengan teknik blokade pleksus brakialis lainnya. Blok saraf aksiler ini sangat bermanfaat bila dilakukan pada operasi lengan bawah. Angka keberhasilan blok saraf perifer akan menjadi lebih tinggi apabila dilakukan dengan menggunakan panduan ultrasonografi dan nerve stimulator.

Penggunaan teknik blok saraf perifer akan sangat menguntungkan pada pasien dengan gangguan fisiologis yang berat karena teknik ini meminimalkan dampak negatif pada fungsi organ bila dibandingkan dengan penggunaan obat pada anestesi umum. Keuntungan lainnya jumlah anestetik lokal yang digunakan akan menjadi lebih sedikit.

\section{Daftar Pustaka}

1. Hadzic A. Peripheral nerve blocks and anatomy for ultrasound guided regional anesthesia. Edisi ke-2. New York: McGrawHill; 2013.

2. Chan VW. Ultrasound Imaging for regional anesthesia. A practical guide. Edisi ke-2, Toronto: Centre for Ultrasound Education; 2013.

3. Morgan GE. Clinical anesthesia. Edisi ke4. United States of America: McGraw-Hill Companies; 2006.

4. Barash PG. Clinical anesthesia. Edisi ke6. United States of America: Lippincott Williams \& Wilkins; 2009.

5. Schwartz JJ. Stoelting's anesthesia and co-existing disease. Edisi ke-5. New York: Elsevier; 2008. 